FEDERAL RESERVE BANK OF SAN FRANCISCO

WORKING PAPER SERIES

\title{
The Illusive Quest: Do International Capital Controls Contribute to Currency Stability?
}

\author{
Reuven Glick \\ Federal Reserve Bank of San Francisco \\ Michael Hutchison \\ Department of Economics, University of California, Santa Cruz
}

May 2010

Working Paper 2010-15

http://www.frbsf.org/publications/economics/papers/2010/wp10-15bk.pdf

The views in this paper are solely the responsibility of the authors and should not be interpreted as reflecting the views of the Federal Reserve Bank of San Francisco or the Board of Governors of the Federal Reserve System. 
The Illusive Quest:

Do International Capital Controls Contribute to Currency Stability?

May 20, 2010

Reuven Glick

Economic Research Department

Federal Reserve Bank of

San Francisco

101 Market Street

San Francisco, CA

reuven.glick@sf.frb.org
Michael Hutchison

Department of Economics, E2

Univ. of California, Santa Cruz

Santa Cruz, CA 95064

hutch@ucsc.edu

\begin{abstract}
We investigate the effectiveness of capital controls in insulating economies from currency crises, focusing in particular on both direct and indirect effects of capital controls and how these relationships may have changed over time in response to global financial liberalization and the greater mobility of international capital. We predict the likelihood of currency crises using standard macroeconomic variables and a probit equation estimation methodology with random effects. We employ a comprehensive panel data set comprised of 69 emerging market and developing economies over 1975-2004. Both standard and duration-adjusted measures of capital control intensity (allowing controls to "depreciate" over time) suggest that capital controls have not effectively insulated economies from currency crises at any time during our sample period. Maintaining real GDP growth and limiting real overvaluation are critical factors preventing currency crises, not capital controls. However, the presence of capital controls greatly increases the sensitivity of currency crises to changes in real GDP growth and real exchange rate overvaluation, making countries more vulnerable to changes in fundamentals. Our model suggests that emerging markets weathered the 2007-08 crisis relatively well because of strong output growth and exchange rate flexibility that limited overvaluation of their currencies.

Keywords: Currency Crises, Capital Controls

JEL: F34, F15, F2, F31, G15, G18 r

We thank Mahir Binici, Kenneth Chow, Ambrish Dongre, and Michael Simmons for excellent research assistance, and Menzie Chinn and Hiro Ito for providing us with their data on capital controls. The views presented in this paper are those of the authors alone and do not necessarily reflect those of the Federal Reserve Bank of San Francisco or the Board of Governors of the Federal Reserve System.
\end{abstract}




\section{Introduction}

Many economists and policymakers have focused on large and volatile capital flows as an underlying source of instability to the international financial system and a causal factor to currency crises. A common view is that liberalization of international capital flows, especially when combined with fixed exchange rates, is either an underlying cause or at least a contributing factor behind these financial disruptions. A common policy prescription under these circumstances is to impose restrictions on capital flows and other international payments with the hope of insulating economies from speculative attacks and thereby creating greater currency stability. The 2007-08 global financial crisis and its effects in emerging markets has contributed even greater urgency to this debate, and the International Monetary Fund now views more favorably than in the past the use of capital controls as a viable policy option to limit excessive capital inflows (see Ostry et. al., 2010) ${ }^{1}$.

However, the empirical literature provides mixed results regarding the effectiveness of capital controls in insulating nations from currency crises (Eichengreen, 2001). Some studies, mainly dealing with individual country experiences, suggest that capital controls are an important instrument in insulating countries from excess exchange rate and capital flow volatility. Rodrik (2002), for example, argues that capital controls were an effective means of stemming the financial crisis in Malaysia in 1998, and was a better alternative to conditions that

\footnotetext{
${ }^{1}$ There are other reasons to impose capital controls in addition to the desire of countries to insulate themselves from currency instability. For example, there is a literature focusing on the links between capital controls and growth (see the survey and analysis in Edison, et. al., 2004). Some authors argue that the impressive economic growth in South Korea in the 1970s-1980s, and China since the mid1980 s, is linked to a range of industrial policies supported in part by tight control on the magnitude and composition of international capital inflows and outflows. However, others argue that it is difficult to establish a robust causal relationship between the degree of financial integration and output growth performance (Prasad et. al., 2003). The focus on our study - the linkage between capital controls and currency crises-is only one consideration among several that should be considered by policy makers when making choices concerning capital controls.
} 
would have been imposed if the country had adopted an IMF program. Other studies, usually based on multi-country panel data sets, suggest that controls are not especially effective in protecting countries from exchange rate instability or capital flow contractions (e.g. Glick and Hutchison, 2005; Edwards, 2005; Eichengreen et al., 2006; and Glick, Guo and Hutchison, 2006).

Much of the empirical work investigating the effectiveness of capital controls is based on the construction of capital control indices - measuring the intensity and strength of controlsthat rely on legislative and administrative rules (de jure) on the inflow and outflow of financial capital and restrictions on international payments. These measures are very useful since they allow many countries to be compared over time and powerful panel-data tests to investigate the effectiveness of capital controls. However, one drawback of capital control indices based on legal and administrative measures is that they do not capture the extent to which they are enforced (that in turn depend on the quality of the bureaucracy and political considerations) or the extent to which they may be circumvented by market forces.

Changes in international and domestic financial markets in recent years may have changed the effectiveness of capital controls in insulating economies from financial disturbances. Firstly, financial and trade integration in the world economy, and the development of global financial markets and financial institutions with increasing global reach, has made it easier to circumvent capital controls. Hence, we would expect de jure capital controls to lose their effectiveness over time in response to an increasingly liberal global financial environment irrespective of the period of time that capital controls have been in place in a given country. That is, we would expect a given level of de jure capital controls to be less effective in maintaining exchange rate and capital flow stability since the latter part of 1990s compared with the 1970s and early 1980s. Secondly, domestic economic forces work to erode the effectiveness of capital 
account restrictions and that they become weaker over time as investors and markets adjust and find ways to circumvent them, and that this characteristic may lead to misleading inferences from empirical work that does not control for this feature of the institutional arrangements. There is a large literature on domestic financial innovation and how this process is partly driven over time by the extent of financial market restrictions. The more binding are restrictions, the larger are the economic benefits from circumventing the controls. And the longer the controls are in place, the more likely that financial innovations have developed in a way that allows agents to circumvent them. We postulate that international financial innovation also partly evolves as a means to circumvent legal and administrative controls on international capital movements.

We address the first issue by measuring the effectiveness of capital controls over various sample periods, testing to see if their effectiveness has changed over time. We address the second issue by constructing a simple "duration adjusted" measure of capital controls (de facto capital controls) and using this index to investigate the effectiveness of capital controls in insulating countries from exchange rate instability. Our measure is linked to the de jure "intensity" of capital controls and the length of time that controls have been in place. Other things equal, our "duration-adjusted" measure declines with the length of the period that controls have been in place. Our premise is that economic forces work to erode the effectiveness of capital account restrictions and that they become weaker over time as investors and markets adjust and find ways to circumvent them. The "erosion" of capital controls may occur faster when the incentive to evade capital controls is large (Gros, 1987). A third issue we address is how capital controls may affect the stability of a currency directly and indirectly by influencing the sensitivity of currencies to changes in macroeconomic fundamentals, such as real GDP growth and real exchange rate overvaluation. We investigate this issue in the context of our nonlinear model by estimating the impact of different values of the macroeconomic fundamentals on 
the likelihood of currency crises probit framework against the background of very restrictive and very relaxed capital controls.

We employ probability models (probit) to measure the impact of changing capital controls on the likelihood of currency and capital flow instability. Our aim is to test how the likelihood of exchange rate crises are influenced over time and by our duration-adjusted measure of capital control intensity. We are especially interested in whether the duration-adjusted measure is better able to explain currency crises than standard de jure measures of capital control intensity. We also use the nonlinear nature of the probit specification to investigate how capital controls may have indirect effects on the vulnerability of countries to currency crises. In particular, we investigate how the presence or absence of capital controls change the sensitivity of currency crises to changes in real GDP growth and real exchange rate overvaluation.

We find that countries with less restrictive capital controls and more liberalized regimes appear to be less prone to currency crises and this characteristic has become more pronounced in recent years (1995-2004). Maintaining real GDP growth and limiting real overvaluation of the currency also help limit the likelihood of currency crises. In addition, we investigate an indirect channel that is largely ignored in the literature and find that the presence of capital controls greatly increases the sensitivity of currency crises to changes in real GDP growth and real exchange rate overvaluation. This heighted sensitivity makes countries with capital controls more vulnerable to macroeconomic volatility.

Our sample period is limited by the availability of data on capital controls, which ends in 2004, and excludes the recent 2007-08 global financial crisis that emanated from the United States. However, our results can help explain why the crisis had relatively limited effects on emerging markets during its initial phase from mid 2007 to mid 2008 (see Dooley and Hutchison, 2009). First, there was no rush to impose capital controls prior to or during this 
period of financial turbulence and therefore no "signaling" of weakness in fundamentals to international investors. Second, macroeconomic fundamentals in most developing countries were relatively strong going into the period of turbulence. Real GDP growth was robust and a degree of exchange rate flexibility, not seen prior to the 1997-98 Asia crisis, limited the degree of real exchange rate overvaluation. The buildup of international reserves by many emerging markets also limited their vulnerability to financial shocks from abroad. It was only after the failure of Lehman Brothers in September 2008 that the crisis intensified dramatically, generating a “common" financial shock to all emerging markets, with capital flows shifting away from countries that were viewed as more vulnerable. This largely distinguishes this crisis-with a common shock emanating from advanced economies, especially the U.S.-- from previous episodes considered in our analysis that were mainly confined to emerging markets.

Section 2 reviews the literature linking capital account restrictions and currency/capital flow stability. Section 3 describes the empirical methodology and data. Section 4 presents the results from testing the effect of capital market restrictions, both over different sample periods and using our duration-adjusted measure of controls, on the likelihood of currency crises. This section also investigates how the presence or absence of capital account restrictions changes the interaction between other important determinants - real GDP growth and real exchange rate overvaluation - and the likelihood of financial crises. Section 5 concludes the study.

\section{Capital Controls, Sequence of Financial Liberalization, and Instability}

The idea of restricting capital mobility as a means of reducing macroeconomic instability has a long history. Indeed, stringent restrictions and limitations on capital flows were the norm during the Bretton Woods era, and over much of the immediate post-war period they were officially sanctioned by most governments in the large industrial countries and by the International Monetary Fund. With the turbulence in exchange markets following the 
introduction of generalized floating, Tobin (1978) argued that a global tax on foreign exchange transactions would reduce destabilizing speculation in international financial markets. After the European currency crisis of 1992-93, Eichengreen and Wyplosz (1993) proposed Tobin taxes to discourage short-term speculators from betting against major currencies. In the aftermath of the Asia currency crisis of 1997-98, Krugman (1998) proposed limiting capital flows for developing countries that were unsuitable for either currency unions or free floating exchange rate regimes. In a similar vein, Stiglitz (2000) and Eichengreen (1999) have argued that developing countries should manage and limit capital flows under certain market conditions.

A large literature on the appropriate sequencing of financial liberalization also suggests that early lifting of controls on the capital account may destabilize the economy. McKinnon (1973, 1993), for example, maintains that decontrol of the capital account should come at the end of the reform sequence, following domestic financial liberalization, bank reform, and trade liberalization. In particular, McKinnon argues that a rapid inflow of (official or private) capital will cause real appreciation of the exchange rate, making it difficult for domestic tradeables producers "to adjust to the removal of protection" (1993, p. 117). Thus, “[a] big injection of capital at the time the liberalization occurs finances an unusual increase in imports while decreasing exports and throws out the wrong long-run price signals in private markets" (ibid., see also Edwards 1984, pp. 3-4).

On the other hand, capital controls may also have a destabilizing effect. Restrictions on the international capital account may in fact lead to a net capital outflow and precipitate increased financial instability. Dooley and Isard (1980) point out that controls preventing investors from withdrawing capital from a country act like a form of investment irreversibility: by making it more difficult to get capital out in the future, controls may make investors less willing to invest in a country. Following this reasoning, Bartolini and Drazen (1997a, b) show 
that imposing capital controls can send a signal of inconsistent and poorly designed future government policies. This channel of influence may be more evident during a period of relative stability in the world economy, such as that termed the "Great Moderation" (of inflation), which prevailed during a substantial part of our sample period. Against the backdrop of a generally stable world economy, the presence of capital controls may signal greater vulnerability to foreign speculative pressure.

Capital controls may also be ineffective and distortionary. Edwards (1999), for example, argues that legal capital restrictions frequently prove ineffective, and are easily sidestepped by domestic and foreign residents and firms. He documents how capital controls may lead to economic distortions and government corruption that in turn contribute to economic instability. Several empirical papers have investigated the experiences with capital controls of selected developing countries. Edison and Reinhart (2001a) focus on the recent experiences of Malaysia and Thailand ${ }^{2}$, while Edwards (1999) and Gregorio et al (2000) examine Chile. In general, these studies have found little effect of capital controls in averting currency crises, at least not without other supporting economic policies. Using various econometric tests and a detailed case study of Chilean controls imposed in the 1980s, for example, Edwards (1999) finds that "...the relative absence of contagion effect on Chile [during the currency crises of the 1990s] is due to its sturdy banking regulation and not to its capital controls policy" (p. 22). This finding is supported by Edwards' (1989) analysis of the role of capital controls in thirty-nine devaluation episodes for twenty-four developing countries over the period 1961-82. He finds that countries typically intensified their control programs in the year before devaluation, and concludes that "[a]t most one can argue that these heightened impediments to trade managed to slow down the unavoidable balance of payments crisis" (pp. 189-90). 
Other studies provide a more mixed view of the effects of capital controls on the factors contributing to currency pressures in developing countries. On the one hand, Bartolini and Drazen (1997a), who survey a number of episodes of capital account liberalization, find that the easing of restrictions on capital outflows often represented early ingredients of a broad set of reforms (including the lifting of various elements of financial repression) and frequently led to large capital inflows. On the other hand, Grilli and Milesi-Ferretti (1995), investigating the effects of restrictions on capital flows in a panel of industrial and developing economies, find that capital controls have a significant negative effect on foreign borrowing, interpreting their use as a means of enforcing financial repression of the economy. They also find that capital controls are associated with lower domestic interest rates, consistent with the view that they limit international arbitrage in asset markets.

Glick and Hutchison (2005) systematically investigate the link between capital controls (or international payments restrictions generally) and currency stability for a broad sample of developing economies. They also investigate other empirical factors explaining both currency crises and capital account restrictions, and causal linkages between the two phenomena. Their results find a statistically significant positive link between capital controls (measured de jure dichotomously as to whether controls are in place or not in place). This result is robust to a variety of specifications and estimation methods that take into account simultaneity issues. Glick, Guo and Hutchison (2006) are concerned that earlier results may be biased by self-selection issues - countries facing exchange rate instability are more likely to impose capital controls, hence a positive link between the two phenomena. They introduce a propensity-score matching methods methodology to address the self-selection problem. This method allows a better measurement of the counterfactual (what would have occurred in the absence of capital controls)

\footnotetext{
${ }^{2}$ Edison and Reinhart (2001b) also include Brazil and Spain in their analysis.
} 
by which to estimate the impact of capital controls on exchange rate instability. Surprisingly, the earlier results hold up and support Bartolini and Drazen (1997a)—countries with capital controls are more likely to experience currency crises.

Several recent studies have investigated the link between capital controls/financial market liberalization and capital flow contractions-reversals-sudden stops using multi-country panel data sets. Eichengreen et al. (2006) find a weak negative association between capital account liberalization and sudden stops but it is generally not statistically significant. Edwards (2005) also finds some evidence of a negative association between capital account liberalization and sudden stops. Edwards (2007), on the other hand, finds evidence that capital controls lower the likelihood of capital flow contractions. He uses three alternative measures of capital controls and investigates both "capital flow contractions" (small and medium-sized contractions in net capital inflows) and sudden stops (major reversals in net capital inflows). More recently Binici et al. (2009) find that controls in emerging markets may significantly reduce equity capital inflows, but have limited effect on debt inflows or capital outflows.

\section{Data and Methodology}

\subsection{Defining Currency Crises}

Our primary indicator of currency crises $\left(x r p \_n w\right)$ is constructed from "large" changes in an index of currency pressure, defined as a weighted average of monthly real exchange rate 
changes $^{3}$ and monthly (percent) reserve losses. ${ }^{4}$ Following convention (e.g. Kaminsky and

Reinhart, 1999), the weights attached to the exchange rate and reserve components of the currency pressure index are inversely related to the variance of changes of each component over the sample for each country. ${ }^{5}$ The exchange rate and reserve data are drawn from the International Monetary Fund's International Financial Statistics CD-ROM (lines ae and 11.d, respectively).

Our measure presumes that any nominal currency changes associated with exchange rate pressure should affect the purchasing power of the domestic currency, i.e. result in a change in the real exchange rate (at least in the short run). This condition excludes some large depreciations that occur during high inflation episodes, but it avoids screening out sizable depreciation events in more moderate inflation periods for countries that have occasionally experienced periods of hyperinflation and extreme devaluation. ${ }^{6}$ Large changes in exchange rate pressure are defined as changes in our pressure index that exceed the mean plus 2 times the

${ }^{3}$ Real exchange rate changes are defined in terms of the trade-weighted sum of bilateral real exchange rates (constructed in terms of CPI indices, line 64 of the IFS) against the U.S. dollar, the German mark, and the Japanese yen, where the trade-weights are based on the average of bilateral trade with the United States, the European Union, and Japan in 1980 and 1990 (from the IMF's Direction of Trade). Most panel studies of currency crises define the currency pressure measure in terms of the bilateral exchange rate against a single foreign country. For example, Kaminsky, Lizondo, and Reinhart (1998) and Kaminsky and Reinhart (1999) measure the real exchange rate for all of the developing countries in their sample against the U.S. dollar. In defining the effective rate in terms of the three major nations likely to be the main trading partners of most developing countries, our approach provides a broader measure than these other studies and is computationally easier to construct than a multilateral exchange rate measure defined in terms of all of a country's trading partners. Possible alternatives, such as the effective exchange rate measures constructed by the IMF, OECD, and others, are not available for a broad sample of developing countries.

${ }^{4}$ Ideally, reserve changes should be scaled by the level of the monetary base or some other money aggregate, but such data is not generally available on a monthly basis for most countries.

${ }^{5}$ Our currency pressure measure of crises does not include episodes of defense involving sharp rises in interest rates. Data for market-determined interest rates are not available for much of the sample period in many of the developing countries in our dataset. 
country-specific standard deviation, provided that it also exceeds 5 percent. ${ }^{7}$ The first condition insures that any large (real) depreciation is counted as a currency crisis, while the second condition attempts to screen out changes that are insufficiently large in an economic sense relative to the country-specific monthly change of the exchange rate. Our sample of currency crisis episodes are listed in Appendix A.

\subsection{Measuring Restrictions on International Payments}

We utilize two measures of capital account restrictions in this study, both based on de jure (legal and administrative controls). Our first measure, kaclosed, is a transformation of the Chinn and Ito (2006 and updated) measure of capital account openness. Their measure is based on underlying data reported in the International Monetary Fund's Annual Report on Exchange Rate Arrangements and Exchange Restrictions (AREAER). They consider the binary indices in four categories: restrictions on capital account transactions, restrictions on current account transactions, requirement to surrender export proceeds and presence of multiple exchange rates. kaopen is the first principle component of these four binary indices (where each value is given a value of 0 if there are restrictions in place, and 1 otherwise; a value of 1 indicates no restrictions, i.e. an "open" capital account). This measure attempts to measure intensity of controls insofar that intensity is correlated with other restrictions on foreign exchange transactions. Our kaclosed measure transforms the Chinn-Ito openness measure to a capital account closed intensity

${ }^{6}$ This approach differs from that of Kaminsky and Reinhart (1999), for example, who deal with episodes of hyperinflation by separating the nominal exchange rate depreciation observations for each country according to whether or not inflation in the previous 6 months was greater than 150 percent, and they calculate for each sub-sample separate standard deviation and mean estimates with which to define exchange rate crisis episodes.

${ }^{7}$ Other studies defining the threshold of large changes in terms of country-specific moments include Kaminsky and Reinhart (1999); Kaminsky, Lizondo, and Reinhart (1998); and Esquivel and Larrain (1998). Kaminsky and Reinhart (1999) use a three standard deviation cut-off. While the choice of cutoff point is somewhat arbitrary, Frankel and Rose (1996) suggest that the results are not very sensitive to the precise cut-off chosen in selecting crisis episodes. 
measure, and rebases it to the $[0,100]$ scale where higher values indicate greater intensity of restrictions on capital account transactions.

Our duration-adjusted measure of capital controls (kaclosed_dur) assumes that administrative controls "depreciate" at the rate: $1 / \exp (0.2 *$ duration $)$, where duration is the number of periods since the last administrative or legal changes in capital controls. A number of depreciation rates were investigated and this rate of decay chosen since it implies a gradual decline in how the effectiveness of controls, with a half-life of about five years, and more intense circumvention of controls when they are most binding and more gradual deterioration in latter periods.

\subsection{Determinants of Currency Crises}

An important part of our work is to identify appropriate control variables in our multivariate probit models. We want to ensure that empirical links between external controls and currency crises are not spurious, attributable to variables omitted from the probit regressions. The theoretical and empirical literature has identified a vast array of variables potentially associated with currency crises (see, e.g. Frankel and Rose, 1996; Kaminsky et al, 1998; Kaminsky and Reinhart, 1999; Eichengreen et al., 2006; Edwards, 2007). The choice of explanatory variables in our benchmark model for the analysis was determined by the questions we posed earlier, the availability of data, and previous results found in the literature. We postulate a "canonical" model of currency crises in order to form a basic starting point to investigate the effects of capital controls. The main source of the macro data is the IMF's International Financial Statistics (CD-ROM). 
Our basic canonical model consists of four macroeconomic control variables that are lagged to limit simultaneity problems. These variables are domestic credit growth (line 32$)^{8}$, the current account to GDP ratio (line 78ald times xrrf divided by 99b) real GDP growth (line 99b.r or 99b.p), and real exchange rate overvaluation. ${ }^{9}$ These variables were found by Glick and Hutchison (2006) to be significant and robust determinants in a model of currency crises. We expect rapid domestic credit growth to be relatively high prior to a currency crisis. A rise in credit growth may signal an expansionary central bank policy, future price increases, expansionary fiscal policy or an unsustainably overheated economy. A larger current account surplus-to-GDP ratio would be expected to lessen the likelihood of a currency crisis. We also expect relatively large exchange rate overvaluation and declining real output growth to be associated with increased likelihood of a currency crisis ${ }^{10}$. Substantially overvalued exchange rates may lead to the expectation that a large adjustment may occur, and declining real GDP growth may signal worsening economic conditions and undermine investor confidence in homecountry investment opportunities. ${ }^{11}$

${ }^{8}$ As in Glick and Hutchison (2006), we also used the log ratio of broad money to foreign reserves (lines 34 plus 35 divided by 1 ld times ae). However, in no instance was this variable statistically significant and was therefore omitted from the regressions.

${ }^{9}$ Following Kaminsky et al (1998) and Kaminsky and Reinhart (1999), among others, we construct the degree of real exchange rate overvaluation from deviations from a fitted trend in the real trade-weighted exchange rate index, where the exchange rate index we fit is the annual average of the monthly series used in constructing the exchange rate component of our currency pressure index (see footnote 5). As reported in Section 5.1, we also consider other measures of overvaluation as a robustness check.

${ }^{10}$ The assumption is that contemporaneous output fluctuations influence the likelihood of currency crises with no reverse causality, i.e. we assume that it takes some time for a currency crisis to influence output. Moreover, we do not measure any longer-term effects on growth that may be associated with the systematic imposition of capital controls as in China presently or South Korea in the 1970s-1980s.

${ }^{11}$ Ostry et. al. (2010) report evidence that some countries with larger stocks of debt liabilities or financial foreign direct investment experienced worse growth slowdowns during the global financial crisis of 2007-08. However, we do not explicitly include balance sheet exposure in our analysis due to data limitations, particularly in terms of currency denomination, for a substantial number of countries in our sample. It is possible that capital controls, to the extent they are effective, could reduce balance sheet exposure, e.g. the exposure to currency mismatches, and thereby reduce the likelihood of a currency crisis (or reduce the output cost of a currency crisis). If this were the case, however, one would expect 


\subsection{Data Sample and Measurement Concerns}

Our data sample is determined by the theoretical determinants of currency market and capital flow volatility and by the availability of data. We do not confine our analysis to countries experiencing currency crises. That is, we include developing and emerging market countries that both did and did not experience a severe currency crisis/speculative attack during the 1975-06 sample period. Using such a broad control group allows us to make inferences about the conditions and characteristics distinguishing countries encountering financial disruptions and others managing to avoid them.

We have a sample of 69 developing and emerging-market countries. ${ }^{12}$ We use annual crisis observations in our analysis. While we employ monthly data for our (real) exchange rate pressure index to identify currency crises and date each by the year in which it occurs, using annual data enables inclusion of a relatively large number of countries.

For each country-year in our sample, we construct binary measures of currency crises, as defined above $(1=$ crisis, $0=$ no crisis $)$. A currency crisis $\left(x r p \_n w\right)$ is deemed to have occurred for a given year if the change in currency pressure for any month of that year satisfies our criteria (i.e. two standard deviations above the mean as well as greater than five percent in magnitude) ${ }^{13}$.

that the presence of capital controls would capture this transmission mechanism and reduce the likelihood of a currency crisis.

${ }^{12}$ Our developing country sample excludes major oil-exporting countries.

${ }^{13}$ In robustness tests, we also consider a indicator that only measures the onset of a crisis (xrp_on) and a measure with windows ( $\left.x r p \_w\right)$. The measure with windows reduces the chances of capturing the continuation of the same currency crisis episode. In particular, after identifying each "large" monthly change in currency pressure, we treat any large changes in the following 24-month window as a part of the same currency episode and skip the years of that change before continuing the identification of new crises. The results were very similar to our baseline case using $x r p \_n w$ and are omitted for brevity. 
With this methodology, we identify 308 currency crises (16 percent of the sample) over the 1975-06 period. ${ }^{14}$

\section{Estimation Results}

\subsection{Descriptive Statistics on Currency Crises and Capital Controls}

Table 1 shows the occurrence of currency crises and capital controls over 1975-2006, and by 5-year intervals (except for the last two years of the sample). The table reports the unconditional frequency of currency crises and presence of capital controls (number of "crisis" or "controls in place" observations, divided by the total number of observations).

The 69 developing countries in our dataset experienced 308 currency crises over 19752006, implying a frequency of 15.8 percent of the available country-year observations. Crises were least frequent during the early (1975-79 period: around 12 percent average frequency) and latter years (2000-2006: around 10.0 percent average frequency), and most frequent during the 1985-89 period (22.6 percent frequency). Currency crises around the world are not uncommon events, and there is no evidence of a trend increase in the frequency of currency crises over time. $^{15}$

Table 1 also reports the intensity of restrictions on capital flows during the period. "Capital controls" ranges from 0 (no controls) to 100 (complete controls). "Capital controlsduration measure" also ranges from 0 to 100 . The table reports average values for the entire sample and 5-year sub-periods. The average intensity of capital controls over the 1975-2004 period was about 68 and 44, respectively, for capital controls and capital controls-duration. The

\footnotetext{
${ }^{14}$ We are limited to $1975-2004$ in our probit regressions, however, because the capital control index stops in 2004.

${ }^{15}$ Currency crises were most frequent in Africa (16.2 percent frequency), and least frequent in Asia (9.6 percent). Despite recent high profile currency crises in Thailand, Malaysia, Indonesia, and Korea, the developing economies in Asia have been less frequently affected by currency instability.
} 
intensity of capital controls was in the 71-78 range during the 1975-94 period, and fell sharply after the mid-1970s (in the 53-59 range) reflecting a major push towards international financial liberalization and decontrol of international transactions. The capital control-duration measure indicates that capital controls were gradually eroding through most of the sample.

\subsection{Probit estimation results}

Our use of probit models allows us to focus on the contribution of payment restrictions to currency crises while controlling for other macroeconomic factors that vary across time and country. We estimate the probability of currency crises using a multivariate probit model for our data set of developing countries over 1975-2006. We observe that either a country at a particular time (observation t) is experiencing a currency crisis (i.e. the binary dependent variable, say $y_{t}$, takes on a value of unity), or it is not $\left(y_{t}=0\right)$. The probability that a crisis will occur, $\operatorname{Pr}\left(y_{t}=1\right)$, is hypothesized to be a function of a vector of characteristics associated with observation $\mathrm{t}, x_{t}$, and the parameter vector $\beta$. The likelihood function of the probit model is constructed across the $n$ observations (the number of countries times the number of observations for each country) and the $\log$ of the function

$$
\ln L=\sum_{t=1}^{n} \mathbf{l}_{t} \ln F\left(\beta^{\prime} x_{t}\right)+\left(1-y_{t}\right) \ln \left(1-F\left(\beta^{\prime} x_{t}\right)\right)_{-}^{-}
$$

is then maximized with respect to the unknown parameters using non-linear maximum likelihood. The function $F($.$) is the standardized normal distribution. All equations are estimated$ with random effects.

In each table we report the effect of a one-unit change in each regressor on the probability of a crisis (expressed in percentage points so that $.01=1 \%$ ), evaluated at the mean of the data. We include the associated z-statistics in parentheses; these test the null of no effect. Note that the sample size of the probit analysis varies depending on the set of variables considered. 
We also report various diagnostic measures. For dependent binary variables, it is natural to ask what fraction of the observations are "correctly called," where, for example, a crisis episode is correctly called when the estimated probability of crisis is above a given cut-off level and a crisis in fact occurs. The chosen cut-off point should reasonably differ depending on the unconditional probability of the event and problem at hand ${ }^{16}$. For our "goodness-of-fit" statistics we consider two different probability cut-offs: 10 percent and 25 percent. These cut-offs bracket the unconditional frequency of currency crises.

\subsection{Has Worldwide Financial Globalization Eroded the Effectiveness of Capital Controls?}

The question of whether the rise in international financial market integration has eroded the effectiveness of domestic restrictions in reducing the likelihood of currency crises is addressed in Tables 2. We consider three samples - the full sample (1975-2004), the early period (1975-1994) and the recent period (1995-2004). We are looking for patterns across time in the effectiveness of capital controls and other factors that may influence the vulnerability of countries to currency instability. Our expectation is that capital controls, to the extent that they were ever effective, are likely to have been less effective in recent years.

The dependent variable denotes whether a currency crisis (Table 2) has occurred for a given observation $^{17}$. The focus explanatory variable for our purposes is the extent of capital account restrictiveness_-kaclosed. The control independent variables are: credit growth (lagged), current account/GDP ratio (lagged), real overvaluation (lagged) and real GDP growth (lagged). Probit models with random effects are estimated. A positive coefficient value of kaclosed indicates that higher restrictiveness of capital controls are associated with increasing likelihood

\footnotetext{
${ }^{16}$ See Greene (2000) for a broader discussion.
} 
of currency crises. Higher credit growth and larger real overvaluation is expected to increase the likelihood of a currency crisis. A larger current account ratio and higher GDP growth is expected to lower the likelihood of a currency crisis.

Table 2 presents the estimates for currency crises, together with summary and goodnessof-fit statistics. There are 1495 observations for the full 1975-2004 sample period. (The number of observations is limited by having observations on each independent variable for a given country at a given point in time). About 81 (44) percent of the observations are predicted accurately, judging by the $25 \%(10 \%)$ cutoff value. Capital controls are highly statistically significant in all three samples, but with a sign suggesting more restrictive controls are associated with a higher probability of a currency crisis. The point estimates (reporting the marginal effects calculated at the mean for all of the independent variables) indicate that controls did not provide insulation against currency crises in either the early or the recent period, and that the point estimate on controls has climbed from 0.12 to 0.15 . . This indicates that capital controls appear to be especially problematic in recent years-- in the era of financial globalization, imposing controls may signal currency weakness that in turn generates loss of confidence, capital outflows and precipitate currency crisis. In particular, a ten point rise in the restrictiveness of controls increases the probability of a currency crisis by 1.5 percent. Stated another way, our results suggest that if a country were to move from complete restrictiveness $($ kaclosed $=100)$ to complete openness $($ kaclosed $=0)$, it would reduce the likelihood of a currency crisis by 15 percent.

This is an empirical result consistent with Glick and Hutchison (2005) and Glick, Guo and Hutchison (2006), and consistent with the signaling theory of the perverse effects of capital

\footnotetext{
${ }^{17}$ This dependent variable measure does not impose windows. We also estimated equations with windows imposed (two years before and after a currency crisis were deleted from the data set) and for the onset of a currency crisis only (i.e. only the first year of a crisis).
} 
controls put forward by Bartolini and Drazen (1997a,b). It is noteworthy that Glick, Guo and Hutchison (2006) find that this result is not due to "self-selection", i.e. countries with weak economic conditions simultaneously impose controls and experience currency instability. (They use a propensity-score matching methodology to control for selection bias and still find a statistically significant positive correlation between controls and probability of a crisis).

The control variables in the three regressions all have the expected signs, but only real overvaluation and real GDP growth are statistically significant. The regressions indicate that the likelihood of a currency crisis is more sensitive to real overvaluation (larger real overvaluation increases the probability of a crisis) and real GDP growth (a higher growth rate lowers the probability of a crisis) during the recent period compared to earlier years when financial globalization was less pervasive.

We looked further into the evolution of capital control effectiveness by considering six five-year sub-samples, starting with $1975-79$ and ending with 2000-04. The objective is to identify more precisely where major shifts may have occurred in the factors contributing to currency crises. The point estimates for the explanatory variables are less statistically significant in the sub-samples, reflecting fewer observations and less power in estimation, and offer no new insights beyond those reported in Table 2. We omit these results for brevity but they are available from the authors upon request.

\subsection{The Erosion of Capital Controls}

Table 3 reports the estimation results from using our kaclosed_dur measure of capital controls for currency crises. As discussed above, this variable "depreciates" the de jure measure of capital controls and is intended to capture the erosion of administrative measures limiting capital flows as agents find ways to circumvent controls and as controls also spur the development of new financial instruments that facilitate moving capital in and out of countries. 
This duration measure of controls is country-specific, and declines over time at a (constant) rate proportional to the level of initial capital controls.

The results with kaclosed_dur are qualitatively similar to those reported earlier using kaclosed but are even larger in magnitude: more restrictive controls are associated with a higher likelihood of currency crisis. The coefficients estimates for the three samples are statistically significant, and the point estimate almost doubles from the early to the recent sample $(0.09$ to 0.17). This again suggests that imposing capital controls in our present environment of “financial globalization" may be more problematic_-signaling weakness and inducing capital flight and currency crises - than in the earlier period.

The coefficient estimates for the control variables in the regressions reported in Table 3 are almost identical to those reported in Table 2 (with kaclosed). Avoiding real exchange rate overvaluation and maintaining strong real GDP growth are critical factors in lowering the likelihood of a currency crisis, and this result is stronger in recent years of financial globalization than in the earlier sample period.

The links between capital account restrictiveness and the probability of a currency crisis is explored further in Figure 1. It shows the nonlinear relationship between the degree of capital account restrictiveness and the probability of a crisis, holding constant all other explanatory variables at their mean values. The Figure is based on the estimates from the more recent sample period (1995-2004). The probability of a currency crisis ranges from 5 percent when the capital account is fully open to 25 percent when the capital account is completely closed.

\subsection{The Linkages between Capital Controls and the Effects of Real GDP Growth and Real}

\section{Overvaluation}

Figures 2 and 3 consider in more detail how different levels of capital controls change the way real GDP and real overvaluation impact the likelihood of currency crises. This is what we 
term the "indirect" effect of capital controls on the likelihood of a currency crisis. In particular, Figure 2 plots the likelihood of currency crises for different rates of real GDP growth, given completely open and completely closed capital accounts. Similarly, Figure 3 plots the likelihood of currency crises for different levels of real exchange rate overvaluation, given completely open and completely closed capital accounts.

Lower real GDP growth increases the likelihood of both currency crises, a non-linear relationship that is increasingly high the lower is output growth. The effects of capital controls on this relationship differ markedly between currency crises. In particular, in Figure 2 there is a substantial difference in the effects of real GDP growth on currency crises depending on whether capital controls are highly restrictive (upper dashed curve) or largely absent (lower solid curve). This difference is negligible at high rates of GDP growth but grows substantially when output falls. In the absence of capital controls, a fall in GDP of 5 percent is associated with about a 15 percent likelihood of currency crisis (with other explanatory variables at their mean values). This probability rises to over 40 percent when capital controls are in place. In development economies, a fall in output of this order of magnitude is not unusual and with capital controls in place puts the economy at risk for a currency crisis..

Figure 3 undertakes a similar analysis for real exchange rate overvaluations. The upper dashed curve (lower solid curve) of Figure 3 shows the likelihood of currency crises to different levels of real overvaluation given that the capital account is completely closed (completely open). As overvaluation increases, the likelihood of a currency crisis increases markedly when the capital account is closed, e.g. the likelihood of a currency crisis is about 10 percent with "undervaluation" of 50 percent and rises to a likelihood of 40 percent with a 50 percent overvaluation. By contrast, when the capital account is open, real overvaluation has a much smaller effect on the likelihood of a crisis and the likelihood is less sensitive to change in real 
overvaluation, i.e. the likelihood ranges from 0 to 10 percent.

\section{Concluding Remarks}

We investigate the effectiveness of capital controls in insulating economies from currency crises, focusing in particular on (1) direct and indirect (working through other fundamental determinants) effects and (2) how these relationships may have changed over time in response to global financial changes and the development of domestic and off-shore financial markets.

Our results suggest that the presence or absence of capital controls appear to have quite different effects on currency crises. Both standard and duration-adjusted measures of capital control intensity (allowing controls to "depreciate" over time) suggest that capital controls have not effectively insulated economies from currency crises at any time during our sample period. The duration-adjusted measure, however, is a more accurate predictor of the likelihood of a currency crisis. Countries with less restrictive capital controls and more liberalized regimes appear to be less prone to currency crises; this characteristic has become more pronounced in the latter years of sample period (1995-2004) when the "Great Moderation" (of inflation) across much of the world reduced economic volatility and likely made countries that imposed capital controls - thereby signaling underlying problems-- more vulnerable to speculative pressures.

In all cases that we investigate, maintaining real GDP growth and preventing real overvaluation of the currency appear to be critical factors preventing currency crises. Moreover, the presence of capital controls greatly increases the sensitivity of currency crises to changes in real GDP growth and real exchange rate overvaluation. In this way, capital controls appear to indirectly make the economy much more vulnerable to macroeconomic fluctuations. By contrast, the presence of capital controls does not have much effect on the sensitivity of currency crises to changes in real GDP growth and real exchange rate overvaluation. 
Our results may help to understand why most emerging markets fared relatively well during the recent global financial crisis that emanated from the United States. First, there was no rush to impose capital controls prior to or during this period of financial turbulence. This meant that no obvious signals of weakness were evident that might have spawned speculative pressures. Second, the apparent decoupling of many emerging markets, particularly in Asia, from developments in the U.S. and other industrial countries may be attributable to their relatively strong output growth and greater exchange rate flexibility that prevented sustained overvaluation in currency values prior to the crisis. This degree of exchange rate flexibility, for example, was not evident prior the 1997-98 Asian crisis. The buildup of international reserves by many emerging markets also limited their vulnerability to the financial shock. It was only after the failure of Lehman Brothers in September 2008 that the crisis intensified dramatically, generating a "common" financial shock to all emerging markets, with capital flows shifting away from countries that were viewed as more vulnerable. This largely distinguishes this crisis-with a common shock emanating from advanced economies, especially the U.S -- from most previous episodes. 


\section{References}

Bartolini, L., and Drazen, A. (1997a). Capital account liberalization as a signal. American Economic Review 87(1), 138-54.

Bartolini, L., and Drazen, A. (1997b). When liberal policies reflect external shocks, what do we learn? Journal of International Economics, 42 (3/4), 249-73.

Binici, M., Hutchison, M., and Schindler, M. (2008). Controlling capital? Legal restrictions and the asset composition of international financial flows. IMF Working Paper 09/08.

Chinn, M. and Ito, T. (2006). What matters for financial development? Capital controls, institutions, and interactions. Journal of Development Economics 81, 163-192.

Dooley, M., and Isard, P. (1980). Capital controls, political risk, and deviations from interest rate parity. Journal of Political Economy 88(2), 370-84.

Dooley, M. and Hutchison, M. (2009). Transmission of the U.S. subprime crisis to emerging markets: Evidence on the decoupling-recoupling hypothesis. Journal of International Money and Finance.

Edison, H.J., and Reinhart, C.M. (2001a). Capital controls during financial crises: the cases of Malaysia and Thailand. In: Glick, R., Moreno, R., Spiegel, M.M., (Eds.), Financial Crises in Emerging Markets, Cambridge University Press, Cambridge, UK, Chapter 12. Also issued as International Finance Discussion Paper no. 662 (March). Board of Governors of the Federal Reserve System. Washington, DC.

Edison, H.J., and Reinhart, C.M. (2001b). Stopping hot money. Journal of Development Economics, 66(2), 533-553.

Edison, H.J., M. Klein, L. Ricci, and Sløk, T. (2004). Capital account liberalization and economic performance: survey and synthesis. IMF Staff Papers, 51(2), 220-256.

Edwards, S. (1984). The Order of Liberalization of the External Sector in Developing Countries. Princeton Essays in International Finance no. 156, Princeton, NJ.

Edwards, S. (1989). Real Exchange Rates, Devaluation and Adjustment: Exchange Rate Policy in Developing Economies. MIT Press, Cambridge, MA.

Edwards, S. (1999). On crisis prevention: Lessons from Mexico and East Asia. NBER Working Paper no. 7233. Cambridge, MA.

Edwards, S. (2005). Capital controls, sudden stops and current account reversals." NBER Working Paper 11170.

Edwards, S. (2007). Capital controls, capital flow contractions, and macroeconomic vulnerability. Journal of International Money and Finance 26, 814-840. 
Eichengreen, B. (1999). Towards a New International Financial Architecture: A Practical PostAsia Agenda. Institute for International Economics. Washington, DC.

Eichengreen, B. (2001). Capital account liberalization: What do cross-country studies tell us? World Bank Economic Review, 15(3), 341-365.

Eichengreen, B., and Wyplosz, C. (1993). The unstable EMS. Brookings Papers on Economic Activity, no. 1, 51-143.

Eichengreen, B., Gupta, P., and Mody, A. (2006). Sudden stops and IMF supported programs. NBER Working Paper 12235 (May).

Esquivel, G., Larrain, F. (1998). Explaining currency crises. Harvard Institute for International Development Working Paper no. 609. Cambridge, MA.

Frankel, J., Rose, A. (1996). Currency crashes in emerging markets. An empirical treatment. Journal of International Economics 41 (3/4), 351-366.

Glick, R., Guo, X. and Hutchison, M. (2006). Currency crises, capital account liberalization, and selection bias. Review of Economics and Statistics, 88(4), 698-714.

Glick, R., Hutchison, M. (2005). Capital controls and exchange rate instability in developing Countries. Journal of International Money and Finance, 24(3), 387-412.

Greene, W.H. (2000). Econometric Analysis. Second Edition. Prentice Hall, Upper Saddle River, NJ.

Gregorio, J., Edwards, S., and Valdés, R. (2000). Controls on capital inflows: Do they work? NBER Working Paper no. 7645. Cambridge, MA.

Grilli, V., and Milesi-Ferretti, G.M. (1995). Economic effects and structural determinants of capital controls. IMF Staff Papers 42(3), 517-51.

Gros, D. (1987). The effectiveness of capital controls: Implications for monetary autonomy in the presence of incomplete market separation. IMF Staff Papers 34 (December), 621-642.

Kaminsky, G., Lizondo, S., Reinhart, C.M. (1998). Leading indicators of currency crises. IMF Staff Papers, 45, 1-48.

Kaminsky, G., and Reinhart, C.M. (1999). The twin crises: the causes of banking and balance-ofpayments problems. American Economic Review, 89(3), 473-500.

Krugman, P. (1998). Saving Asia: It's time to get radical. Fortune, September 7, 74-80.

McKinnon, R. (1973). Money and Capital in Economic Development. Brookings Institution, Washington, DC. 
McKinnon, R. (1993). The Order of Economic Liberalization: Financial Control in the Transition to a Market Economy. Second Edition. Johns Hopkins Press, Baltimore, MD.

Ostry, J., Ghosh, A., Habermeier, K., Chamon, M., Qureshi,M., Reinhardt, D. (2010). Capital inflows: The role of controls. IMF Staff Position Note, Feb. 19, SPN/10/04.

Prasad, E., Rogoff, K. Wei, S.-J. and Kose. M.A. (2003). Effects of financial globalization on developing countries: Some empirical evidence, IMF Occasional Paper 220.

Rodick, D. (2002). Did the Malaysian capital controls work? (with Ethan Kaplan). In: S. Edwards and J. Frankel, eds., Preventing Currency Crises in Emerging Markets, The University of Chicago Press for the NBER.

Stiglitz, J. (2000). What I saw at the devaluation. The New Republic, April 24.

Tobin, J. (1978). A proposal for international monetary reform. Eastern Economic Journal, $4(3 / 4), 154-59$. 
Table 1: Currency Crises and Capital Controls, Unconditional Frequency (in percent)

\begin{tabular}{|l|c|c|c|c|c|c|c|c|}
\hline & $\begin{array}{c}1975- \\
2006\end{array}$ & $\begin{array}{c}1975- \\
1979\end{array}$ & $\begin{array}{c}1980- \\
1984\end{array}$ & $\begin{array}{c}1985- \\
1989\end{array}$ & $\begin{array}{c}1990- \\
1994\end{array}$ & $\begin{array}{c}1995- \\
1999\end{array}$ & $\begin{array}{c}2000- \\
2004\end{array}$ & $\begin{array}{c}2005- \\
2006\end{array}$ \\
\hline Currency crises $^{\mathrm{a}}$ & 15.76 & 12.17 & 16.90 & 22.59 & 18.58 & 17.52 & 10.74 & 5.56 \\
\hline (Number of crises) $(308)$ & $(32)$ & $(48)$ & $(68)$ & $(60)$ & $(58)$ & $(35)$ & $(7)$ \\
\hline Capital controlsb1 $^{b}$ & 67.96 & 71.17 & 75.77 & 77.89 & 71.63 & 59.41 & 53.05 & (N.A.) \\
\hline Capital controls $^{\mathrm{b} 2}$ & 43.7 & 48.28 & 46.17 & 44.74 & 41.51 & 46.52 & 35.77 & (N.A.) \\
\hline
\end{tabular}

a Number of crises divided by total country-years with available data. Number of crises in parentheses.

Currency crisis measure is "xrp_nw"

b1: kaclosed, b2: kaclosed_dur (average of capital controls) 
Table 2: Determinants of Currency Crises

\begin{tabular}{|c|c|c|c|}
\hline Explanatory Variable & $1975-2004$ & 1975-1994 & 1995-2004 \\
\hline $\begin{array}{l}\text { Capital acct. controls (t) } \\
\text { (ka closed) }\end{array}$ & $\begin{array}{c}0.14587 \\
(3.936)^{* * \star}\end{array}$ & $\begin{array}{l}0.11665 \\
(2.040)^{* *}\end{array}$ & $\begin{array}{l}0.14815 \\
(3.015)^{* * *}\end{array}$ \\
\hline Credit growth (t-1) & $\begin{array}{l}0.01076 \\
(0.416)\end{array}$ & $\begin{array}{l}0.01451 \\
(0.466)\end{array}$ & $\begin{array}{l}0.00589 \\
(0.113)\end{array}$ \\
\hline Current account/GDP (t-1) & $\begin{array}{l}-0.12531 \\
(0.850)\end{array}$ & $\begin{array}{l}-0.0693 \\
(0.358)\end{array}$ & $\begin{array}{l}-0.25967 \\
(1.189)\end{array}$ \\
\hline Real overvaluatio & $\begin{array}{c}0.13194 \\
(3.448)^{\star \star \star}\end{array}$ & $\begin{array}{c}0.14454 \\
(3.063)^{* \star *}\end{array}$ & $\begin{array}{l}0.15333 \\
(2.102)^{* \star \star}\end{array}$ \\
\hline Real GDP growth (t-1) & $\begin{array}{l}-1.02153 \\
(5.509)^{\star * \star}\end{array}$ & $\begin{array}{l}-0.88291 \\
(3.558)^{\star * *} \\
\end{array}$ & $\begin{array}{l}-1.16942 \\
(4.289)^{* * *}\end{array}$ \\
\hline \multicolumn{4}{|c|}{ Summary Statistics } \\
\hline No. of Crises & 235 & 152 & 83 \\
\hline No. of Observations & 1495 & 918 & 577 \\
\hline Log likelihood & -598.837 & -387.711 & -210.016 \\
\hline \multicolumn{4}{|c|}{ Goodness-of-fit ( $25 \%$ cutoff) a } \\
\hline$\%$ of obs. correctly called & 81 & 80 & 85 \\
\hline$\%$ of crises correctly called & 25 & 22 & 29 \\
\hline$\%$ of non-crises correctly called & 91 & 91 & 95 \\
\hline \multicolumn{4}{|c|}{ Goodness-of-fit ( $10 \%$ cutoff) a } \\
\hline$\%$ of obs. correctly called & 44 & 37 & 57 \\
\hline$\%$ of crises correctly called & 84 & 89 & 77 \\
\hline$\%$ of non-crises correctly called & 36 & 27 & 54 \\
\hline
\end{tabular}

Note: The table reports the coefficients in the Random Effects Probit Regressions with associated z-statistic (for hypothesis of no effect) in parentheses below. Results significant at 1, 5, and 10 percent levels are indicated by ${ }^{* * *},{ }^{* *}$, and ${ }^{*}$, respectively. Constant included, but not reported.

Coefficient reported are the marginal effects evaluated at the mean of independent variables.

Coefficients are multiplied by 100 giving marginal effects in terms of $\%$.

a Goodness-of-fit statistics defined respectively as $(A+D) /(A+B+C+D), A /(A+C)$, and $D /(B+D)$, where $A(C)$ denote number of crises with predictions of crises above (below) probability cutoff and $B(D)$ denote number of corresponding non-crises with predictions of crises above (below) the cutoff. 
Table 3: Determinants of Currency Crises: Duration-Adjusted Capital Controls

\begin{tabular}{|c|c|c|c|}
\hline Explanatory Variable & $1975-2004$ & $1975-1994$ & $1995-2004$ \\
\hline $\begin{array}{l}\text { Capital acct. controls_duration (t) } \\
\text { (ka_closed_dur) }\end{array}$ & $\begin{array}{c}0.13706 \\
(3.862)^{\star * *}\end{array}$ & $\begin{array}{l}0.09236 \\
(1.883)^{*}\end{array}$ & $\begin{array}{c}0.16974 \\
(3.238)^{* * *}\end{array}$ \\
\hline Credit growth (t-1) & $\begin{array}{l}0.01552 \\
(0.602)\end{array}$ & $\begin{array}{l}0.01288 \\
(0.411)\end{array}$ & $\begin{array}{l}0.01116 \\
(0.210)\end{array}$ \\
\hline Current account/GDP (t-1) & $\begin{array}{l}-0.14017 \\
(0.959)\end{array}$ & $\begin{array}{l}-0.09034 \\
(0.470)\end{array}$ & $\begin{array}{l}-0.20548 \\
(0.939)\end{array}$ \\
\hline Real overvaluation (t-1) & $\begin{array}{c}0.14262 \\
(3.677)^{* * *}\end{array}$ & $\begin{array}{c}0.15207 \\
(3.197)^{\star * *}\end{array}$ & $\begin{array}{r}0.14852 \\
(2.048)^{\star *}\end{array}$ \\
\hline Real GDP growth (t-1) & $\begin{array}{l}-1.01074 \\
(5.429)^{\star * *}\end{array}$ & $\begin{array}{l}-0.87866 \\
(3.528)^{* * *}\end{array}$ & $\begin{array}{l}-1.14344 \\
(4.188)^{\star * *}\end{array}$ \\
\hline \multicolumn{4}{|c|}{ Summary Statistics } \\
\hline No. of Crises & 235 & 152 & 83 \\
\hline No. of Observations & 1495 & 918 & 577 \\
\hline Log likelihood & -599.625 & -388.149 & -209.211 \\
\hline \multicolumn{4}{|c|}{ Goodness-of-fit (25\% cutoff) a } \\
\hline$\%$ of obs. correctly called & 81 & 80 & 86 \\
\hline$\%$ of crises correctly called & 23 & 24 & 29 \\
\hline$\%$ of non-crises correctly called & 92 & 91 & 96 \\
\hline \multicolumn{4}{|c|}{ Goodness-of-fit (10\% cutoff) a } \\
\hline$\%$ of obs. correctly called & 44 & 37 & 59 \\
\hline$\%$ of crises correctly called & 86 & 89 & 72 \\
\hline$\%$ of non-crises correctly called & 36 & 26 & 57 \\
\hline
\end{tabular}

Note: The table reports the coefficients in the Random Effects Probit Regressions with associated z-statistic (for hypothesis of no effect) in parentheses below. Results significant at 1,5, and 10 percent levels are indicated by ${ }^{* * *},{ }^{* *}$, and ${ }^{*}$, respectively. Constant included, but not reported.

Coefficient reported are the marginal effects evaluated at the mean of independent variables.

Coefficients are multiplied by 100 giving marginal effects in terms of $\%$.

a Goodness-of-fit statistics defined respectively as $(A+D) /(A+B+C+D), A /(A+C)$, and $D /(B+D)$, where $A(C)$ denote number of crises with predictions of crises above (below) probability cutoff and $B(D)$ denote number of corresponding non-crises with predictions of crises above (below) the cutoff. 
Figure 1. Probability of Currency Crisis given Capital Account Restrictions

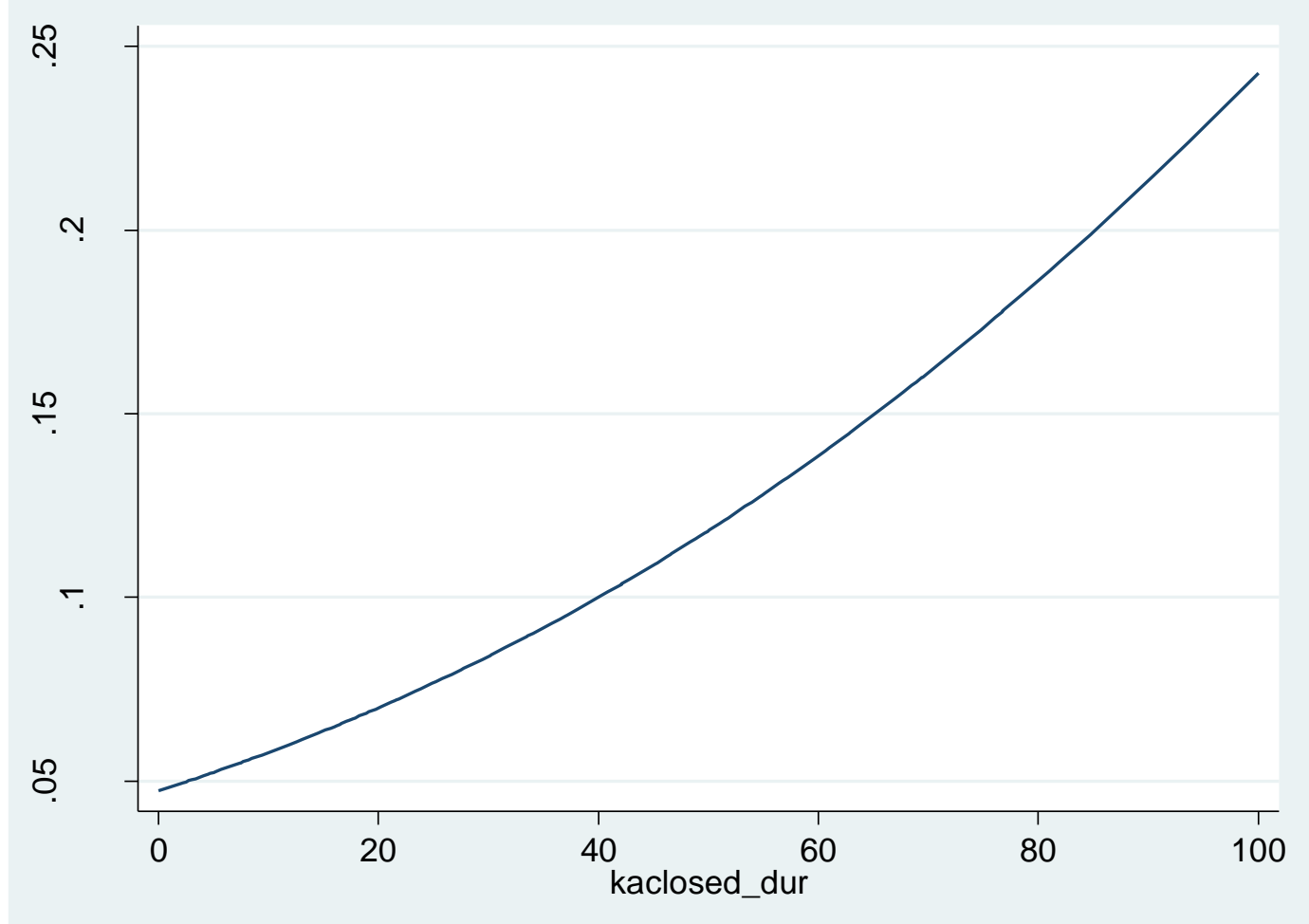


Figure 2. Probability of Currency Crisis given Real GDP Growth For Fully Open $(=0)$ and Closed $(=100)$ Capital Account

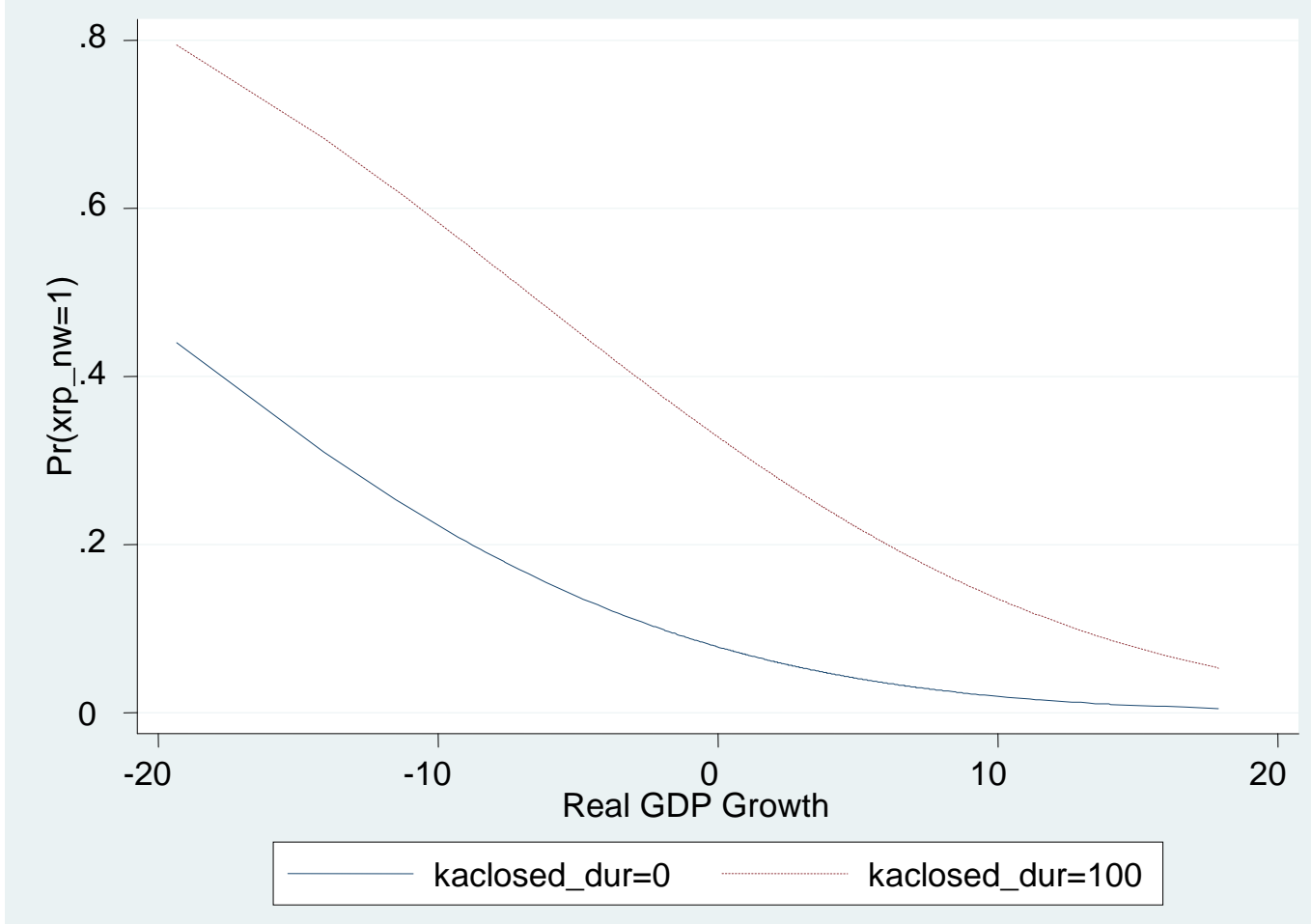

Note: The upper (lower) curve is the case where the capital account is fully closed (open). 
Figure 3. Probability of Currency Crisis given Real Overvaluations

For Fully Open $(=0)$ and Closed $(=100)$ Capital Account

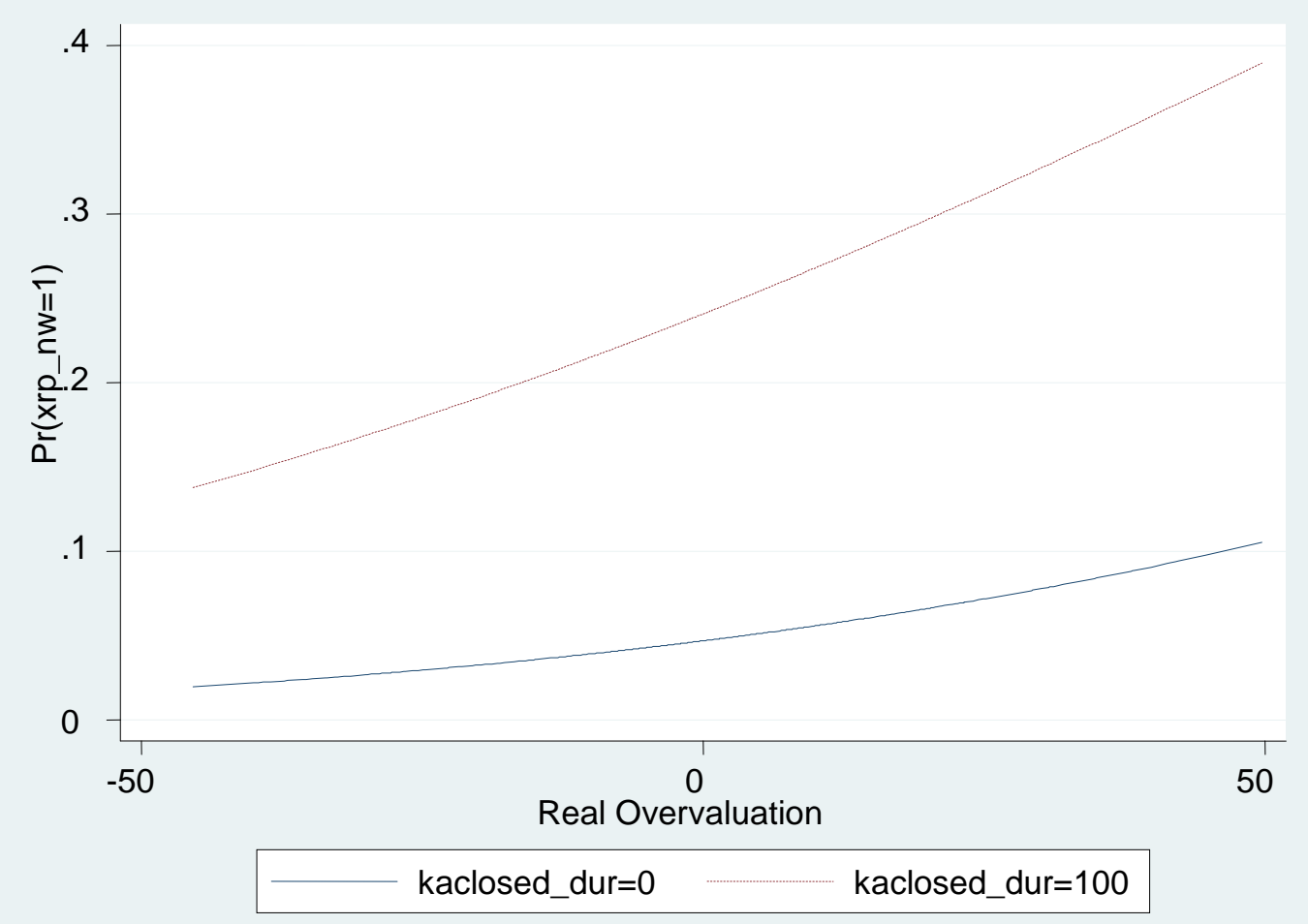

Note: The upper (lower) curve is the case where the capital account is fully closed (open). 
Appendix A. Currency Crisis Episodes

\begin{tabular}{|c|c|}
\hline Country & Currency Crisis Episodes \\
\hline Argentina & $1975-1976,1982-1983,1989-1991$ \\
\hline Bangladesh & $1975-1976$ \\
\hline \multicolumn{2}{|l|}{ Belize } \\
\hline Bolivia & $1981-1985,1988-1991$ \\
\hline Botswana & 1982, 1985-1986, 1996, 1998, 2001-2002, 2005- 2006 \\
\hline Brazil & 1982-1983, 1987, 1990, 1998-2000, 2002 \\
\hline Burundi & $1976,1983,1986,1988-1989,1991,1997-2003$ \\
\hline Cameroon & $1982,1984,1994$ \\
\hline Chile & 1985 \\
\hline \multicolumn{2}{|c|}{ China, P.R.: Hong Kong } \\
\hline Colombia & $1985,1997-1999,2002,2006$ \\
\hline Costa Rica & 1981 \\
\hline \multicolumn{2}{|l|}{ Cyprus } \\
\hline Dominican Republic & $1985,1987,1990,2004$ \\
\hline Ecuador & $1982,1985,1988$ \\
\hline Egypt & 1979, 1989-1991, 2003 \\
\hline El Salvador & 1986,1990 \\
\hline \multicolumn{2}{|l|}{ Equatorial Guinea } \\
\hline Ethiopia & 1992 \\
\hline Fiji & 1986-1987, 1998 \\
\hline Ghana & $1978,1986-1987,1990,2000$ \\
\hline \multicolumn{2}{|l|}{ Grenada } \\
\hline Guatemala & $1986,1989-1990$ \\
\hline Guinea-Bissau & 1991, 1995-1996, 2003 \\
\hline Guyana & 1987, 1989-1991, 1999 \\
\hline Haiti & 1991, 1993-1994, 2000, 2002 \\
\hline Honduras & 1990 \\
\hline Hungary & $1989,1995,2003,2006$ \\
\hline India & 1975, 1978, 1983, 1986, 1991, 1993, 1995 \\
\hline Indonesia & $1978,1983,1986,1997-1998$ \\
\hline Jamaica & $1978,1983-1984,1990-1992$ \\
\hline Jordan & $1983,1987-1989,1992,2002$ \\
\hline Kenya & 1975, 1981-1982, 1985, 1993-1995, 1997, 2003 \\
\hline Korea & $1980,1997-1998$ \\
\hline
\end{tabular}




\begin{tabular}{|c|c|}
\hline Lao People's D. R. & $1995,1997-1999$ \\
\hline Madagascar & 1984, 1986-1987, 1991, 1994, 1996, 2004 \\
\hline Malawi & $1985-1987,1992,1994,1998$ \\
\hline Malaysia & $1986,1997-1998$ \\
\hline Mali & 1993 \\
\hline Malta & 1992,1997 \\
\hline Mauritius & $1979,1981,1998$ \\
\hline Mexico & $1976,1982,1985,1994-1995$ \\
\hline Morocco & 1983-1985, 1990, 2001 \\
\hline Mozambique & 1993,1995 \\
\hline Myanmar & 1975- 1977 \\
\hline Nepal & 1975, 1978, 1981-1982, 1984-1986, 1991, 1993, 1995 \\
\hline Nicaragua & 1979-1980, 1993, 1995 \\
\hline Nigeria & 1986, 1992-1993, 1999 \\
\hline Pakistan & $1999-2000$ \\
\hline \multicolumn{2}{|l|}{ Panama } \\
\hline Paraguay & 1984- 1986, 1988-1989, 1992, 1999, 2002 \\
\hline Peru & $1976-1977,1979,1981,1987-1988$ \\
\hline Philippines & $1983-1984,1986,1997,2000$ \\
\hline Romania & 1990-1992, 1997, 1999 \\
\hline Sierra Leone & 1988-1990, 1997-1999 \\
\hline Singapore & 1975,1998 \\
\hline South Africa & 1975, 1984-1986, 1996, 1998, 2001-2003, 2006 \\
\hline Sri Lanka & 1975, 1977, 1998 \\
\hline Swaziland & 1975, 1979, 1982, 1985-1986, 1998, 2001, 2003, 2006 \\
\hline Syrian Arab Republic & $1977,1982,1988$ \\
\hline Thailand & 1997-1999 \\
\hline Trinidad \& Tobago & $1985,1988,1993$ \\
\hline Tunisia & 1993 \\
\hline Turkey & 1978-1980, 1994, 2001, 2006 \\
\hline Uganda & $1981,1987-1989$ \\
\hline Uruguay & 1982-1984, 2002 \\
\hline Venezuela & $1982,1984,1986,1989-1990,1994-1996,2002-2003$ \\
\hline Zambia & 1985-1987, 1993-1994 \\
\hline Zimbabwe & 1982, 1991, 1993-1994, 1997-1998, 2000 \\
\hline
\end{tabular}

